\title{
Possibilities of using digital technologies in recruitment
}

\author{
Alfiya Tasmukhanova ${ }^{1},{ }^{*}$ Alina Dubinina ${ }^{2}$, Irina Zakharova ${ }^{3}$ \\ ${ }^{1}$ FSBEI HE Ufa State Petroleum Technical University, Ufa, Russia \\ ${ }^{2}$ LLC RN-BashNIPIneft, Ufa, Russia \\ ${ }^{3}$ Ufa Higher School of Economics and Management of the Ufa State Petroleum Technical University, Ufa, Russia \\ *Email: aetasm@mail.ru
}

\begin{abstract}
The article substantiates the need to introduce digital technologies into the recruitment and hiring system. According to the maturity model stages for attracting talent, which companies must pass to achieve professional maturity in recruitment, now in Russia, there are all prerequisites for using HR Digital. The proposed methodology of using Boolean search technology in the recruitment process for oil and gas companies is described. The matrix of the professional and technical competencies model developed by the authors is described. Using this matrix, it is proposed to assess HR specialists' proficiency in tools and technologies. The competence model is a set of key competencies that employees need to achieve the company's strategic goals successfully. The approbation of the developed recruitment algorithm is given on the example of LLC "RN-BashNIPIneft". The advantages of using a Boolean query were shown by the example of searching for candidates for a replacement position in the specified enterprise. Based on the study results, a preferred strategy for developing the recruitment system for 28 corporate research and design institutes was formed.
\end{abstract}

Keywords: Recruitment, Recruitment method, Boolean search, Social networks, Competence model, Headhunting, Candidate, Position, Automated system.

\section{BASIC PROVISIONS}

1. The ability to use modern digital technologies in the current conditions is one of the most valuable competencies of a recruiter today.

2. The proposed method of implementing boolean search technology into the recruiting system will allow the company's management to be provided with quality candidates in the shortest possible time and contribute to an increase in enterprise productivity by more than $40 \%$.

3. The implementation of the recommended strategy in PJSC "NK Rosneft" will significantly reduce the time for closing vacancies (based on the experience of LLC "RN-BashNIPIneft").

\section{INTRODUCTION}

The basis of any modern organisation is the staff that ensures the effective use of all types of resources available to the organisation. The more tightly the team works, the more efficient and competitive the company.
Suppose the initial choice falls on an insufficiently qualified applicant, then in the future. In that case, this threatens the organisation with significant time and financial losses, which directly affects the company's competitiveness and effectiveness. Organisations are faced with the need to have the most effective search, selection, hiring, and adaptation of personnel [1, 2].

As foreign and domestic practice shows, there is currently a great interest in the digital sphere and modern digital tools in Russia and the world in their creation and implementation in personnel recruitment [3, 4]. A large selection of Internet services offered on the market opens up new opportunities for employers to increase business efficiency and reduce direct and indirect economic costs.

Social networks continue to dominate over other sources of personnel search [5, 6]. The improvement of website functions continues, the search for employees of various profiles is facilitated, and applicants' coverage is expanding. Due to the current economic situation in Russia and the world, companies are forced to develop and move to more advanced levels of maturity. 


\section{RECRUITING TECHNOLOGIES AND TOOLS}

A comparative analysis of Russian and foreign recruiting [7] shows that the domestic searching system of qualified personnel has room to grow. Although many Russian leading oil and gas companies actively use external recruiting or headhunting, this is the end of updating the recruitment and hiring processes [8]. It is necessary to attract and adapt the workforce with the help of new management tools, methods and technologies [9]. First of all, it is required to develop automation, robotisation and digitalisation of recruiting, cognitive recruitment, and, of course, HR branding.

HR Digital is a popular market trend that we want to pay special attention to. Digital technologies are being actively introduced into recruitment: many companies already use predictive analytics, machine learning and artificial intelligence. At the same time, technology allows you to automate the screening and recruitment process, and interviews are now conducted not only by specialised employees but also by chatbots and robots

A comparative analysis of the stages of recruitment in Russia and the world [10] shows that today recruitment technologies are mainly involved in the search, placement of vacancies and processing responses from candidates.

Depending on how actively the organisation implements and uses modern technologies and tools, it is possible to judge the level of business development (or its specific direction) or its readiness to reach a new level of development. Also, the level of technology implementation is affected by the development and the manufacturability of the recruiter himself. Bersin by Deloitte consultants have developed a unique maturity model for attracting talent - Talent Acquisition [11]. This tool describes the four stages of development that each company must go through to achieve professional maturity in recruitment. The model helps to understand the current state of the company, as well as to determine the set of skills and technologies necessary to achieve the next stage of development [12].

According to experts, the recruitment function of most Russian companies is at the stage of standardised operational recruitment" (2nd level of maturity); a smaller percentage of companies are at the 3rd level of maturity ("Integrated Strategic Personnel Planning"), and only a few have reached the 4th level of strategic planning.

\section{BOOLEAN SEARCH - AS A MODERN WAY OF RECRUITMENT}

We suggest paying attention to the Boolean search method. It implies that the employer sets a task in a specific market segment to find a candidate for certain parameters (his qualifications, professionalism, motivation for further development, personal qualities, etc.) and determine the most suitable one.

In [13], a comparative characteristic of the technology of Boolean search for recruitment is given compared to the classical method of searching through a work site.

The machine learning algorithm will take into account several hundred features and, based on them, will make you a selection of the most qualified resumes in any search engine, including search engines (Google, Yandex), social networks (Vkontakte, Facebook, LinkedIn), job sites (HeadHunter, Avito, SuperJob), professional forums (AmazingHiring, Kaggle), which are used by oil companies, and, in particular, in the context of the automated personnel accounting system of LLC "RN-BashNIPIneft".

Booleans make it possible to combine words and phrases using standard prepositions AND, OR, NOT known as Boolean operators. Boolean operators allow limiting and thereby expanding the scope of search queries (Table 1).

The world of HR and recruitment has changed so much that social networks have become the same daily tool as HeadHunter. Learning how to work with social networks as efficiently as possible is vital, both in standard ways and with digital tools. To assess the level of competence and the level of proficiency in modern digital tools for finding candidates, it is necessary to evaluate the recruiter [14]. As a method of employee evaluation, the idea of assessing the knowledge and skills of an HR specialist using a model of professional and technical competencies that any specialist of an oil and gas company should possess was proposed (Figure 1).

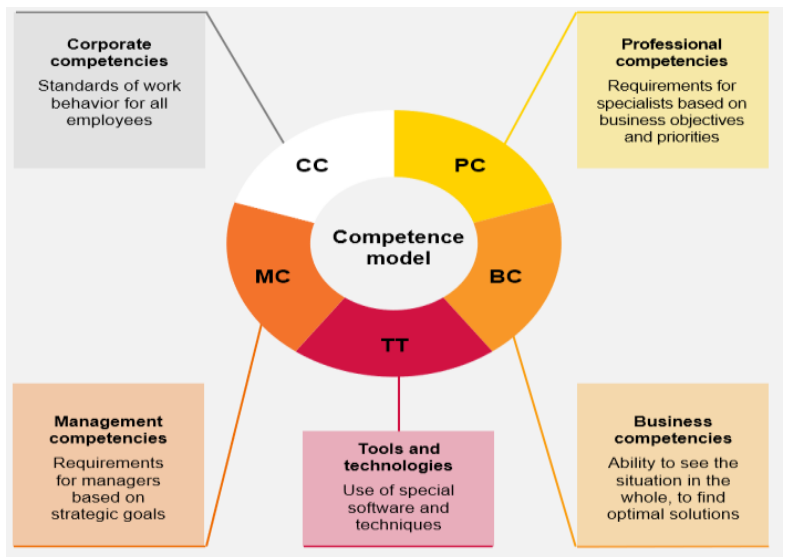

Figure 1 Competence model matrix (developed by the authors).

Competence has specific levels of its development, differing in the depth of possession of relevant knowledge and skills: 
Table 1. Symbols and special words for Boolean search in the system

\begin{tabular}{|l|c|c|}
\hline \multicolumn{1}{|c|}{ Function } & Google & Yandex \\
\hline Search by exact keyword & '"' & \& \\
\hline Operator combining words or expressions in a search query & AND & ( ) \\
\hline Search by any of the words & OR & ( ) \\
\hline $\begin{array}{l}\text { The operator that sets the priority of a part of the search query } \\
\text { Excluding a word from search results }\end{array}$ & title: \\
\hline $\begin{array}{l}\text { Restriction on the word in the page title } \\
\text { Restriction on a specific site }\end{array}$ & intitle: & site: \\
\hline $\begin{array}{l}\text { URL restriction. The search is limited to a group of pages whose URL } \\
\text { Contains the specified fragment }\end{array}$ & inurl: \\
\hline $\begin{array}{l}\text { Search with a missing word, part of a word } \\
\text { PDT (MS Excel), } \\
\text { File type restriction: }\end{array}$ & * & * \\
\hline
\end{tabular}

1) basic. The employee has a general idea of the areas of application of the methodology or technology.

2) knowledge. The presence of theoretical knowledge about the methodology or technology and the procedure for their application.

3) experience. The experience of independent application of the methodology or technology.

4) advanced. The ability to exercise technical control over the application of the methodology, technology.

5) expert. The ability to independently develop or lead the development of new methods or technologies.

\section{APPROBATION OF THE PROPOSED APPROACH}

One of the main activities of LLC "RNBashNIPIneft" and other research and design institutes that are part of the corporate research and design complex (CRDC) PJSC "NK "Rosneft" is the development of modern software and the creation of innovative technologies for the development and operation of deposits. A highly qualified and highly specialised professional is required to perform such tasks as IT developer, chief engineering engineer, mining engineer, a specialist in modelling and analysis of well and reservoir studies, head of the geomechanical research laboratory, etc. [15].

To increase the search area for complex and unique specialists, it is necessary to use sophisticated search technologies - recommendation search, direct search, headhunting, Boolean search [16].

Let's imagine the current recruitment algorithm (stage II) LLC "RN-BashNIPIneft" using the scheme (Figure 2). LLC "RN-BashNIPIneft". It shows that an HR specialist is looking for the easiest way to close a vacancy. HR specialist first goes to the most popular job search site Head Hunter.ru and place an application. But there is a problem - on the job site, you can find candidates for a typical position - economist, accountant, marketing specialist, etc. What should I do if a company needs a highly specialised specialist? What to do if there are very few responses to a vacancy for such a position or the target audience of applicants is not present at HH.ru? The solution is to use Boolean search technology, including in social networks - professional telegram channels, professional social network - LinkedIn, the most popular social network in the world - Facebook. 


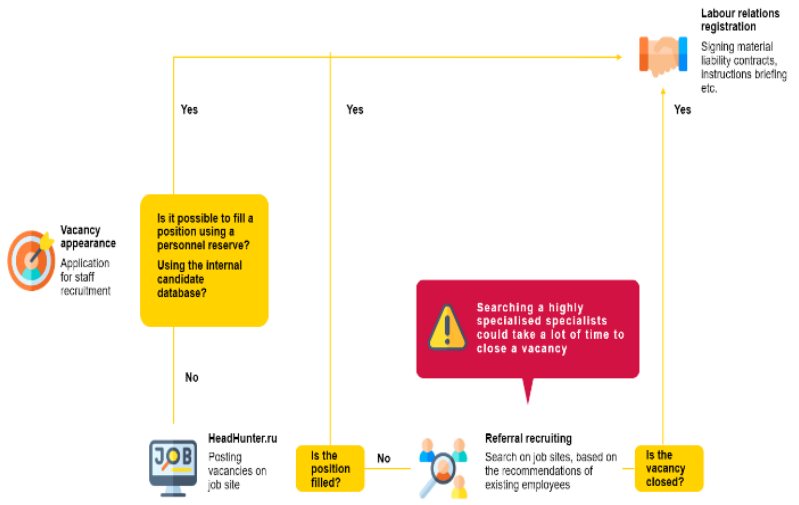

Figure 2 The current recruitment algorithm.

As a result of a Boolean query on LinkedIn, in just 20 minutes, 1 candidate was found ideally suited to the requirements of the enterprise. The candidate has $\sim 7$ years of work experience, many skills and lives in Ufa. The search for the same candidate, but using standard system filters, took 40 minutes. The only problem is that the candidate already has a job. But here, a competent recruiter can use headhunting technology and lure a unique specialist to the company.

Closing such specific, unique positions takes a lot of time. The recruiter of LLC "RN-BashNIPIneft" must have a high level of competence and have experience completing problematic, unique and challenging to close vacancies. LLC "RN-BashNIPIneft" uses a classical model of personnel assessment for four types of competencies - professional, corporate, business and managerial. Let's evaluate the recruiter using the "Evaluation 360" technology. The recruiter himself (selfassessment), the manager, colleagues and subordinates (if any) participate in the assessment. In LLC "RNBashNIPIneft", the recruiter does not have subordinates; thus, the score is "Evaluation 270".

According to the results obtained, the recruiter corresponds to the level of proficiency in the competence of "Recruitment" and "HR analytics in recruitment", has the competence of "Communications Management" at a level beyond the required, and there is a slight lack of proficiency in the "Personnel search" technology. The recruiter must be sent for training

It should be noted that Boolean search is exceptionally effective in collaboration with an automated personnel accounting system. In September 2020, an automated personnel accounting system was purchased for LLC RN-BashNIPIneft. This software structures business processes in the HR department is a powerful optimisation tool that allows you to increase employees' efficiency (Table 2) significantly.

An analysis of the recruiter's work activity over the past 6 months showed that the recruiter began to save up to $40 \%$ of working time for closing a vacancy.

\section{CONCLUSION}

Due to the current economic situation in Russia and the world, companies are forced to develop and move to more advanced levels of maturity. In 2020, organisations faced the need to be able to adapt the recruiting system to a remote mode. Following the current conditions, the advantages of the recruiter's remote work and digital recruiting elements for remote work were highlighted.

Table 2. Comparative characteristics of the recruitment system of LLC "RN-BashNIPIneft" before and after the implementation of the automated system

\begin{tabular}{|l|l|}
\hline \multicolumn{1}{|c|}{ Before the system implementation } & \multicolumn{1}{c|}{ After the system implementation } \\
\hline $\begin{array}{l}\text { Documents in different formats. The processes are not } \\
\text { transparent. Making edits takes place in different } \\
\text { environments }\end{array}$ & $\begin{array}{l}\text { Built-in system of electronic approval of vacancies and } \\
\text { people. Working with documents in a single environment }\end{array}$ \\
\hline $\begin{array}{l}\text { Manual generation of a report on employees, any dates } \\
\text { and periods, as well as - automatically split data into } \\
\text { periods by quarters, months or weeks }\end{array}$ & $\begin{array}{l}\text { Visualised online analytics for all applicants in all } \\
\text { conditions }\end{array}$ \\
\hline $\begin{array}{l}\text { Manual resume selection. Responses are complicated } \\
\text { to sort }\end{array}$ & $\begin{array}{l}\text { There is a tool for the operational management of } \\
\text { vacancies (you can publish ads, send vacancies for } \\
\text { approval, send invitations to calendars to participants) }\end{array}$ \\
\hline $\begin{array}{l}\text { The time spent on the selection, selection and offer to } \\
\text { the candidate is } ~ 3 \text { weeks }\end{array}$ & $\begin{array}{l}\text { The time spent on the selection, selection and offer to the } \\
\text { candidate is } \sim 2 \text { weeks }\end{array}$ \\
\hline $\begin{array}{l}\text { Time spent on documents preparing for approval } \sim 3 \\
\text { weeks }\end{array}$ & $\begin{array}{l}\text { The time spent on documents preparing for approval is } \\
1.5 \text { weeks }\end{array}$ \\
\hline
\end{tabular}


Based on the results of the study, a methodological approach was formed for the introduction of Boolean search technology into the recruitment process of oil and gas companies, which, unlike existing digital methods of recruitment, can be used in various search engines (Google, Yandex), in social networks (Vkontakte, Facebook, LinkedIn), on job sites (HeadHunter, Avito, SuperJob), in professional forums (AmazingHiring, Kaggle), and in general contributes to the improvement of the automated personnel accounting system.

The proposed Boolean search technology for the specified parameters on the Internet gives more relevant results, saving the recruiter from viewing an extra hundred pages. With the search on non-widespread sites for finding an employee, such as social networks, professional communities, messengers, etc., the Boolean search will be an advantage in finding a unique specialist.

\section{REFERENCES}

[1] T.V. Baskina, Techniques of successful recruitment [Tekhniki uspeshnogo rekrutmenta], Moscow: Alpina Publisher, 2017, 288 p.

[2] V. Borodai, Crowd recruiting as the competence assessment of applicants' service company // International Scientific Review 3 (2017) 709-716.

[3] Types of interviews and methods of their conduct [Vidy sobesedovanij i metody ih provedenij] / HRDirector. [electronic resource]. Access mode: http://www.hr-director.ru/article/63393-red-w9vidy-sobesedovaniy-i-methody-ih-provedeniya

[4] Marco De Micheli, Acht Wege für eine bessere Auswahl von Bewerbern [Electronic resource] / Marco De Micheli // Magazin. Werkzeuge fur Organisation and Management, 02/18/2015. Access mode: http://www.businesswissen.de/artikel/personalauswahl-acht-wege-fuereinebessere-auswahl-von-bewerbern/

[5] D.K. Zakharov, Recruitment using social networks [Podbor personala s ispol'zovaniem social'nyh setej] // Management [Upravlenie] 6(1) (2018) 2530.

[6] Von Carsten C. Schermuly, Tobias Schröder, Jens Nachtwei, Karl Gläs. Recruiting im Jahr 2020 [Electronic resource] / Von Carsten // Harvard Business manager, No. 11, 2012. Access mode: http://www.harvardbusinessmanager.de/heft/artikel la-865357.html

[7] A.I. Dubinina, Prerequisites for improving recruiting at oil and gas complex enterprises [Predposylki sovershenstvovaniya rekrutinga na predpriyatiyah neftegazovogo kompleksa] // Collection of scientific papers of the II All-Russian
Scientific and Practical Conference [Sbornik nauchnyh trudov II Vserossijskoj nauchnoprakticheskoj konferencii], 2019, pp. 42-45.

[8] S.V. Kapitanov, Headhunting and executive search. How to entice an employee from another organisation? [Hedhanting i executive search. Kak peremanit' sotrudnika iz drugoj organizacii?] // Problems of Science [Problemy Nauki] 4(86) (2017) 37-46.

[9] A.V. Ryabova, Modern methods of recruitment: mobile recruiting and recruiting through social networks [Sovremennye metody podbora personala: mobil'nyj rekruting i rekruting cherez social'nye seti] / A.V. Ryabova // Actual problems of the humanities proceedings of the XII International Scientific and Practical Conference of Students, Postgraduates and Young Scientists [Aktual'nye problemy gumanitarnyh nauk trudy XII Mezhdunarodnoj nauchno-prakticheskoj konferencii studentov, aspirantov i molodyh uchenyh]. - National Research Tomsk Polytechnic University [Nacional'nyj issledovatel'skij tomskij politekhnicheskij universitet], 2013 [Electronic resource]. Access mode: http://www.lib.tpu.ru/fulltext/c/2013/C20/134.pdf

[10] A.E. Tasmukhanova, A.I. Dubinina, Questions of recruiting automation using remote selection methods [Voprosy avtomatizacii rekrutinga s pomoshch'yu metodov distancionnogo podbora] // Collection of scientific papers of the III All-Russian Scientific and Practical Conference [Sbornik nauchnyh trudov III Vserossijskoj nauchnoprakticheskoj konferencii], 2020, pp. 18-20.

[11] Overview of personnel selection methods [Obzor metodov otbora personala] / HR-Portal [electronic resource]. Access mode: $\underline{\text { https://hr- }}$ portal.ru/article/obzor-metodov-otbora-personala

[12] N.G. Bobkova, Personnel management system in current conditions [Sistema upravleniya personalom v sovremennyh usloviyah] // Modern technologies. System analysis, Modelling [Sovremennye tekhnologii, Sistemnyj analiz, Modelirovanie] 1 (2016) 209-223.

[13] A.E. Tasmukhanova, A.I. Dubinina, Methods of using the Boolean search model in recruiting [Sposoby ispol'zovaniya modeli buleva poiska $\mathrm{v}$ rekrutinge] // Collection of scientific papers of the IV All-Russian Scientific and Practical Conference [Sbornik nauchnyh trudov IV Vserossijskoj nauchno-prakticheskoj konferencii], 2020, pp. 3133. 
[14] B.Yu. Higir, Non-traditional methods of recruitment and evaluation of personnel [Netradicionnye metody podbora i ocenki personala] / B.Yu. Higir, M.: Personnel Management [Upravlenie personalom], 2003, 163

p.

[15] R.R. Khairullina, A.E. Tasmukhanova, Questions of formation of a professional standard in the oil and gas industry [Voprosy formirovaniya professional'nogo standarta $\mathrm{v}$ neftegazovoj otrasli] // Electronic scientific journal Oil and Gas Business [Elektronnyj nauchnyj zhurnal Neftegazovoe delo] 5 (2011) 451-460.

[16] M.M. Gajfullina, G.Z. Nizamova, A methodological approach to developing a strategy for efficient staff management in oil company // In the collection: IOP Conference Series: Earth and Environmental Science, International Science and Technology Conference "EarthScience", 2020, p. 062041. 